\title{
Conceptual and Methodological Research of Xenophobia in Social Sciences
}

\author{
Vladimir Alexandrovich Kirik ${ }^{1}$
}

\author{
Alexander Vladimirovich Popov² \\ Oxana Yuryevna Posukhova ${ }^{3}$
}

Anton Vladimirovich Serikov ${ }^{4}$

Olga Mikhailovna Shevchenko 5

\begin{abstract}
${ }^{1}$ Southern Federal University, Rostov-on-Don, Russian Federation ${ }^{2}$ Southern Federal University, Rostov-on-Don, Russian Federation ${ }^{3}$ Southern Federal University, Rostov-on-Don, Russian Federation ${ }^{4}$ Southern Federal University, Rostov-on-Don, Russian Federation ${ }^{5}$ Southern Federal University, Rostov-on-Don, Russian Federation Email: aserikov@inbox.ru
\end{abstract}

Doi:10.5901/mjss.2015.v6n4s4p183

\begin{abstract}
The article presents a conceptual and methodological analysis of xenophobia study in social sciences. In order to investigate the phenomenon of xenophobia, the authors propose to use the methodology of constructive realism that makes it possible to substantiate the social nature of criteria for defining the "outsiders" and their dynamics. By interpreting xenophobia as a way of organizing social relations based on the antagonistic opposition of "insiders - outsiders," the authors state that this method allows us to control human behavior forming the desired images of "outsiders" in our minds. The implementation of the methodology of constructive realism within the study of xenophobia offers the possibility to distance oneself from the purely psychological and sociobiological approaches dominating in the social cognition, and to consider xenophobia as a sufficiently complex and contradictory social phenomenon that, on the one hand, is one of the ways to protect the identity of an individual and a group of individuals in the unpredictable and dangerous world, and on the other hand, is an element of political technology that constructs the image of an "outsider" for achieving specific goals.
\end{abstract}

Keywords: xenophobia, methodology of constructivist realism, social identity, social markers, in-group favoritism, ethnocentrism, ethnic prejudices, ethnosocial stratification.

\section{Introduction}

An unacceptably high level of xenophobia is one of the important problems of the modern world. Despite the fact that in the XXI century, the humanity acquires a qualitatively new global organization of the world aimed at creating a unified global community, the intensification of the integration processes is accompanied by the opposite trend-the increase of disintegration and chaos in the world. Within the context of the world chaotization, a commitment to its streamlining starts growing, which stems from the humans' need to feel safe. This need creates in people the desire to separate themselves from foreign "worlds," to hold the visible and invisible borders between the "insiders" and "outsiders," and thus to cope with the fears generated by the "outsiders."

The scientific interest in the problem of xenophobia is substantiated not only by the perception of xenophobia as a socially dangerous phenomenon. It is also determined by the fact that the opposition of "insiders - outsiders" is of a universal nature and acts as an integral component of the ontological concepts of the binary world structure (Soldatova and Makarthuk, 2006). A human desire to divide the world into "insiders" and "outsiders" is one of the basic characteristics of the human nature and the central mechanism of xenophobia, which can be used for different purposes, both for the personal safety precautions, and in the struggle for power, territory, and wealth.

Initially, the study of xenophobia was carried out within the framework of psychological knowledge in the context of systematization and classification of phobias. Within the framework of socio-psychological knowledge, xenophobia is often considered in the same context as the concept of "ethnocentrism." For the first time, this term was used by the 
American sociologist W. Sumner (Sumner, 1954). The works of B. Berelson and G. Steiner (Berelson and Steiner, 1964), and R.S. Krech (Krech, 1962) are dedicated to the roles of prejudices in the study of xenophobia. There are also works that deal with the issues of xenophobia substantiated by the religious factors (Van der Noll and Saroglou, 2015; Helbling, 2014; Cinnirella, 2013), the problems of regional perceptions of islamophobias (Abbas, 2007), and russophobias (Tsygankov, 2013).

In the Russian social knowledge, the problem of different manifestations of xenophobia in the former Soviet Union is embodied in the works of such authors as V. I. Mukomel (Mukomel, 2014) and V. N. Iarskaia (larskaia, 2012). The regional dimension of the aggressive forms of xenophobia was deeply studied by the scientists of the Rostov School of Sociology: I.P. Dobaev, A.V. Serikov, and O.M. Shevchenko (Dobaev et al., 2012). The authors consider the problem of xenophobia in the context of safety in the South of Russia based on the historical material and in the light of the modern development trends of the region.

\section{Methodology of the Scientific Research}

The theoretical and methodological basis of the article is formed by the studies conducted in the tideway of the transdisciplinary methodology, the basic framework, ideas, and principles of which were developed within foreign and domestic psychology, social psychology, sociology, cultural and social anthropology. The choice of transdisciplinary methodology is substantiated by the fact that at present, the concept of "xenophobia" is used in various fields of knowledge from clinical and social psychology to sociology and political science, affecting the adjacent heterogeneous semantic fields. Perhaps, this is the reason why xenophobia has not yet acquired the status of a strict scientific term, which, however, is typical of the most concepts that are operated by liberal arts and social sciences. As rightly observed by K. Popper, the complexity of studying the subject area of social sciences is that it "... is in constant motion. The sphere of the public life, fully covered by the history flow, has no sustainable principles" (Popper, 1992). That is, when the knowledge on social problems is of not quite definite nature and is considered in the subject field of various sciences, there is a need for transdisciplinary research allowing to account for the fundamental complexity of xenophobia as a social phenomenon and to consider it on different levels of the social reality, which interrelations are of not linear, but network character. In our opinion, in the study of xenophobia, it is also advisable to use the methodology of constructive realism, according to which the structure of the world is the result of its social construction. The development of the constructivist realism methodology is associated with the names of P. Berger and T. Lukman, the authors of the book "The Social Construction of Reality" (Berger and Lukman, 1996). Constructive realism bases on the fact that the construction of social reality occurs exceptionally within a certain cultural and epistemological context, i.e. it is not of arbitrary nature, but to a certain degree corresponds to the social reality itself (Lubskii, 2012).

\section{Results}

In the scientific knowledge, the psychological and sociobiological research methodologies prevail with regard to the issue of xenophobia. Within their framework, xenophobia is interpreted as a tendency, natural for humans, to think of the world in the "insiders-outsiders" terms. At the same time, we often neglect the fact that the drawn border is not always natural, that it is socially organized, and its establishment is accompanied by the purposeful formation of the image of an "outsider." At applying the methodology of constructive realism in the study of xenophobia, we open a methodological opportunity to substantiate the social nature of criteria for defining "outsiders," as well as their dynamics. The implementation of the constructive realism methodology allows us to consider xenophobia as a way to organize social relations on the basis of the antagonistic opposition of "insiders-outsiders," which are developed within the historically specific social conditions and based on the concepts of a particular community concerning equality, justice in distribution of life's benefits, and the conditions of meeting the material, social, and spiritual needs (Shevchenko, 2013).

According to their understanding, the authors examine the phenomenon of xenophobia based on the social identity concept. The social identity acts as the original baseline of xenophobia, since it can be only achieved through the intergroup comparison, which intensifies the importance of group membership and stimulates the group feelings. The perceptions of the groups of "insiders" and "outsiders" are the result of categorization and identification that, being a necessary component of the reality perception process, as a rule, are based not on the personal experience of interaction with the members of various groups, which is often missing, but on the schemes already existing in the group discourse. The functional connection between xenophobia and identity manifests itself in the fact that xenophobia sets the "horizon" of the group consciousness "we - they," "insiders - outsiders," using mistrust, fear, and hatred for the "outsides" as the basis of social cohesion (Dobaev et al., 2012). 
It is important to note that in the structure of identification, it is customary to distinguish two types: the positive and the negative identifications. The identification process is always accompanied by the confrontation of these two components. If in the process of positive identification, the positive self-representations and the accompanying feelings (pride, dignity, comfort, and solidarity) are accentuated, then the negative identification involves the negative assessments of outsiders, and the complete "we - they" opposition. The mechanism of negative identification is described in detail by the founder of the identity theory E. Erikson who stated that "... any positive identity...can be also determined through the negative images and...our... identity exists due to the humiliation of others" (Erikson, 1968).

Understanding xenophobia as a means to organize social relations based on the antagonistic opposition of "insiders - outsiders" allows us to single out its main characteristics:

1. Binarity in the construction of social relations. The desire to divide the world into "insiders" and "outsiders" is considered as one of the basic settings of the identification process and the central mechanism of xenophobia. Binarity in the construction of social relations always implies the existence of a structural assessment of the "insiders" and "outsiders." The tough polarization of assessments and the opinionated and judgmental thinking of the "insiders" and "outsiders" is one of the attributes of xenophobia. The consolidation and polarization of positive and negative assessments occur, which are derived from the sharpness of boundaries between the "good" and the "bad," and from the absence of transitions between them. The negative assessment of "outsiders," as an integral component of xenophobia, justifies all forms of violence in relation to them.

2. Negativism towards "outsiders." The affects are the basis of negative reactions to the "outsiders." These are mainly the fear, anger, disgust, contempt, and envy. In turn, fear provokes dislike, which can escalate into hatred and hostility. And then the opposition of "insiders - outsiders" is fully activated and determines the formation of negative stereotypes and prejudices, repelling images of the enemy, and different forms of discrimination. Anger, disgust, and contempt are the emotional mechanisms that take an "outsider" out of the active zone of the accepted moral standards, and thereby, catalyze the directions of social violence. The envy as a socio-psychological state is also capable of provoking negativism within the interpersonal and intergroup relations. Thus, the affective component of xenophobia (fear, anger, disgust, contempt, and envy) is the basis of negative reactions to the "outsiders," including the hostile ones.

3. Hostility towards "outsiders." The hostility towards "outsiders" has not only psychological, but also social ground. The social nature of hostility manifests itself in the fact that a person is able to show aggression towards the identifiable "outsiders" not only in the situation of real danger, but also in the situation of its absence, both on the basis of its foreseeing or projecting in the future, and on the basis of infusion. The hostility towards identifiable "outsiders" is constructed through a variety of super-biological systems - a language, mythological models of the world, religious beliefs, scientific doctrines, and a political discourse (larskaia, 2012).

For this reason, xenophobia can be used for different purposes, both to provide personal safety, and to struggle for power, territory, and wealth. Xenophobia, as a way of organizing social relations based on the antagonistic opposition of "insiders - outsiders," allows us to control human behavior forming the desired images of "outsiders" in our minds.

The construction of relations based on the antagonistic opposition of "insiders - outsiders" uses the social markers to highlight the "outsiders," which determine the object-based directionality of xenophobia. The social markers represent a set of symbols that define the dominant criteria for the identification of a personality or a group. Based on the social markers, which are drawing the border in the relations of "insiders - outsiders," it is possible to execute a specific classification of xenophobia. We proceed from the fact that a type of xenophobia is a socially constructed negative image of an "outsider" based on the identification markers dominating in a specific historical period of social development. In the history of mankind, the most common types of xenophobia, although rarely manifested in their purest form, are the ethnic xenophobia, religious xenophobia, racial xenophobia, antisemitism, ideological xenophobia, and their mixed types.

An important factor for the understanding of the social nature of xenophobia is the specification of the levels of its origin: the socio-psychological and the ideological ones.

On the socio-psychological level, xenophobia is primarily of protective-compensatory nature and is a natural response to the ongoing social processes and changing situations. In this case, the basis of xenophobia, as a means of constructing social relations, is the protection of the vital needs of an individual, group, or society. On this level, xenophobia is fed with the stereotypes, prejudices, and attitudes formed in the everyday communication.

The ideological level of the xenophobia origin is implemented in the spiritual sphere, particularly in religion, politics, and scientific doctrines. Herein, xenophobia is governed not so much by the vital affects as by a spiritual search for selfdetermination, political interests, rational justification of personal exclusivity, and as a consequence by this exclusivity, as well as by the legitimation of social inequality in accessing economic, political, and other resources of particular groups. 
In general, the results of the scientific study suggest that xenophobia, firstly, is closely associated with social identity that defines a set of key markers, on which basis the identification of "insiders" and "outsiders" is carried out; secondly, xenophobia acts as a protective-compensatory mechanism for consolidating and preserving the identity; thirdly, xenophobia is a way of legitimizing the relations of economic and political inequalities in a social environment; fourthly, xenophobia is an effective instrument of political mobilization of social groups (ethnic, religious, national, etc.) for achieving their goals.

\section{Discussion}

The contemporary scientific literature often demonstrates a terminological confusion, wherein xenophobia is identified with the concept of ethnocentrism, racism, nationalism, extremism, etc., or is merely reduced to the term's etymology. In this connection, it seems appropriate to analyze the theoretical and methodological aspects of the xenophobia study presented in the social sciences.

Despite the fact that the first study of xenophobia started within the framework of the psychological knowledge in the context of systematization and classification of phobias, xenophobia in the society, as opposed to merely neurotic phobias, does manifest itself solely through the social interaction, being a consequence of structuring and the subsequent differentiation of the social reality into "insiders" and "outsiders."

In this aspect, xenophobia starts to be considered in the context of studying the intergroup relations of hostility, and is often identified with such a concept as the in-group favoritism providing for the in-group consolidation, which is usually accompanied by the intergroup hostility. Researchers find the essence of the in-group favoritism in its being a trend to favor the members of one's own group somehow as opposed to the members of any other group (Tajel and Turner, 1979). This can be manifested both in the externally observed behavior and in the processes of social perception, for example, in the formation of opinions, judgments, estimates, etc., relating to the members of the groups of insiders and outsiders.

In the ethnopsychology, ethnocentrism is a phenomenon close to xenophobia. One of the first researchers dealing with ethnocentrism, W. Sumner, defined it as the propensity of consciousness to evaluate the world around through the prism of traditions and values of one's own ethnic group (Sumner, 1959). Ethnocentrism simultaneously includes positive attitudes towards the group of insiders and negative attitudes towards the groups of outsiders, i.e. to those social groups that are somewhat different from the group of insiders. According to W. Sumner, this leads to the formation of a double moral standard in assessing the behavior within the group and in relation to the "outsiders." The researcher rightly believed that all peoples were ethnocentric in the sense that when assessing others, they rely on the values of their own ethnic group. To substantiate his point of view, he outlined numerous ethnographic facts providing evidence of that in most cases people a priori prefer the members of their own groups and humiliate, discredit those who do not belong to these groups. Ethnocentrism is such a deposition of consciousness, wherein the members of one's own group are treated only positively, and the outsiders are treated as barbarians, savages, infidels, and so on. W. Sumner put forward a very fruitful idea on the positive impact of a hostile environment or an external aggression on the internal cohesion of the community.

The further study of ethnocentrism, as a phenomenon closely related to xenophobia, continued in the context of the theory of social identity (Brewer and Campbell, 1976). The empirical foundations of this theory were laid by M.B. Brewer and D. Campbell who with their classic experiments have proved that it is quite enough to establish groups, name them, and cause rivalry between them, so that such an initial manifestation of ethnocentrism as a group-centrism will appear. These ideas were systematized by D. Campbell and called the "Theory of Conflict of the Real Groups." According to this theory, rivalry is quite a sufficient condition for the emergence of ethnocentrism, and further of xenophobia.

According to social psychologists, within the intergroup relations, the principle of attributive prejudice is also observed in addition to the in-group preference. It is comparable to the sense of a priori self-esteem existing on an individual level, by virtue whereof all good deeds are always ascribed to the members of the group of insiders, and bad deeds-to the group of outsiders. Using the experimental and theoretical methods, the authors have managed to prove that even a group with the minimum number of members can create both attribute prejudices and prepossession of memory, and, therefore, real ethnocentrism. In our opinion, these extremely important and interesting facts contribute to the understanding of the instrumental nature of xenophobia.

According to the researchers, ethnocentrism is rooted in the specific features of the primitive psyche that negatively or cautiously responds to all, which is unknown. Nevertheless, ethnocentrism is eventually substantiated by the ethno-cultural apperception, i.e. by the specifics of the entire process of socialization of a personality in a particular 
ethno-cultural environment: by the perception and consolidation in the consciousness of the prevailing in it stereotypes as well as the systems of values and traditions.

It should be noted that there is no consensus among the researchers in assessing the role of ethnocentrism for both an individual and the society. Some scientists believe that ethnocentrism is a negative social phenomenon, which is equivalent to nationalism and even racism; others consider ethnocentrism an integral feature of the ethnic consciousness with a typical thereof overestimation of the group of insiders that is necessary to maintain a positive in-group psychological climate. We believe that ethnocentrism, like any other social and psychological phenomenon, cannot be regarded only as something positive or on the contrary negative, and therefore a judgment of its value is hardly acceptable. Although ethnocentrism often appears to be an obstacle to easy intergroup interaction, it simultaneously accomplishes such an important for the group function as maintenance of positive identity and even preservation of the integrity and specificity of the social unification. It is possible to agree with I.S. Kon with regard to his opinion that interethnic intolerance is not a direct consequence of ethnocentrism. It occurs only when the "real or imagined differences are raised to the superior quality and transform into a hostile mental attitude with respect to a certain ethnic group; the attitude, which disunites peoples first psychologically, and then theoretically, and substantiates the policy of discrimination (Kon, 1998). I.S. Kon named this phenomenon an ethnic prejudice.

In the work by B. Berelson and G. Steiner "The Human Behavior. A summary of Scientific Data," a prejudice is defined as "hostile attitude towards an ethnic group or its members as such" (Berelson and Steiner, 1964).

In general, the results of the scientific researches of the nature of ethnic prejudices within the scientific literature are reduced to a generalized affirmation based on the concept of hostile attitude to all members of an ethnic group that are of more emotional, rather than rational nature (Gasanov, 1998). This is actually emphasized by the etymology of the term "preconception," "prejudice," that is something that precedes conscious mind and conviction. Probably, due to the previously mentioned factor, this phenomenon is extremely stable, is poorly influenced by the rational arguments, and the scientific study of the ethnic prejudices is extremely complicated. Here it is possible to agree with I.S. Kon who believes that "no matter how essential the individual psychological processes are, the key to understanding the nature of ethnic prejudices lies not in them, but in the history of the society and in the structure of social consciousness.... Their interpretation is the task for history and sociology" (Kon, 1998).

Thus, a prejudice is primarily a social fact, a public phenomenon. A separate individual derives his ideas from the stereotypes of public consciousness, and assimilates them in the process of socialization. Therefore, to understand the nature of ethnic prejudices underlying xenophobia, it is necessary to study not so much a person being ridden by prejudices, as the society that generates these prejudices.

The modern sociological theories offer broader methodological possibilities in the study of the xenophobia's social causes, since on the one hand, they call for the autonomy of the social reality in relation to the biological and mental realities, and on the other hand, for the primacy of the society and its ability to "produce" a social individual.

Currently, the actual problem of sociology becomes the study of the relationship between ethnicity and social stratification. A profound study on the ethnic group statuses was conducted by L. Hagendorn (Hagendorn, 1995). By studying the issue of ethnic intolerance in the youth environment of the Netherlands, he came to the following conclusions: an ethnic status in the multi-ethnic regions is an essential part of the human's social well-being. Its low level generates a sense of national infringement, and its high level creates snobbery towards the ethnic minorities. Both these factors cause latent or overt ethnic xenophobia.

The Russian sociologists also note that xenophobia is substantiated by the presence within the modern multicomponent societies of an ethno-stratification system, wherein the civilizational boundary serves as a dominant factor (Social Inequality, 2002). In this ethno-stratification system, the dominated position is occupied by the ethnic groups that have reached the industrial phase of the socio-economic development, and the subordinate position is taken by the agricultural ethnic groups. According to scientists, such a situation inevitably gives rise to xenophobia (Mukomel, 2014).

It should be noted that the ethnosocial stratification of the society is always accompanied by intense interethnic rivalry for certain amenities (for example, resources, economic opportunities, and political rights), which are equally valued by all ethnic groups, and are not perceived as strictly assigned to one of them. Therefore, under conditions of the acute interethnic rivalry for limited prestigious niches, the psychological components of xenophobia (fears or negative stereotypes) can become particularly relevant (Diatlov, 2011). The ethnic groups that demonstrate their disproportionately high level of representation in the low-status socio-economic strata usually conclude that the whole system is structured not in their favor. Consequently, resentment against the dominant group arises.

The advantage of the above-mentioned methodological model of the xenophobia causes research is that it considers the vertical and horizontal stratification only as the ideal types, noting that the modern polyethnic systems are 
characterized by the diagonal asymmetry of ethnosocial structure and the mobility of boundaries between the ethnic and non-ethnic (social) division. Theoretically, even in the polyethnic societies, the distribution of economic benefits, social status, and political power can be ethnically neutral. But in fact, during the distribution of resources, which is performed by a modern state, we can frequently observe an imbalance of the ethnic criteria. And these asymmetric correlations transfer the ethnicity from the field of culture into the realm of policy (Levin et al., 2012).

\section{Conclusion}

Proceeding from the above- mentioned, we come to the following conclusion.

A theoretical and methodological analysis of the xenophobia study in social sciences suggests that this phenomenon has not only the psychological basis, but also the socio-cultural nature. The latter manifests itself in the fact that, firstly, the objects of xenophobia vary depending on the socio-cultural context, and secondly, the subjects of xenophobia themselves are included into the complex system of social relations determining their consciousness and behavior. Moreover, xenophobia is a sufficiently complex and contradictory social phenomenon that, on the one hand, acts as one of the forms of the socio-psychological protection of the identity of an individual or a group of individuals in an unpredictable and dangerous world, and on the other hand, is an element of the political technology that constructs the image of an "outsider" for achieving specific goals. Understanding the instrumental nature of xenophobia offers the opportunity of studying the specific features and causes of xenophobia in the conditions of the contemporary transformation processes generated by globalization.

In this regard, it is further planned to study the factors that can provoke xenophobia in the modern world, and namely, the existence of the deep social asymmetry in the global economic and political systems generating a strict status hierarchy of the national states within the unipolar world system; the inequality of the economic and political opportunities; and the enhancement of the international and interregional stratification and competition.

\section{Acknowledgement}

The article was financially supported by the internal grant of the Southern Federal University No. 213.01-072014/15ПЧВГ "Threats to the National Security in the Context of the Geopolitical Competition and the Patterns of the Aggressive and Hostile Behavior of the Youth."

\section{References}

Abbas, T. (2007). Muslim Minorities in Britain: Integration, Multiculturalism and Radicalism in the Post-7/7 Period. Journal of Intercultural Studies, 28(3), 287-300.

Berelson, B., \& Steiner, G.A. (1964). Human Behavior. An Inventory of Findings. New York.

Berger, P., \& Luckman, T. (1966). The Social Construction of Reality: A Treatise in the Sociology of Knowledge (pp. 240). Garden City, NY: Anchor Books.

Brewer, M.B., \& Campbell, D.T. (1976). Ethnocentrism and Intergroup Attitudes: East African Evidence. New-York: Halsted, Wiley.

Cinnirella, M. (2013). Think Terrorist, Think Muslim? Social-Psychological Mechanisms Explaining Anti-Islamic Prejudice. Islamophobia in the West: Measuring and Explaining Individual Attitudes, 2013, 179-90.

Diatlov, V. (2011). Grazhdane blizhnego zarubezh'ia i drugie... Dinamika formirovaniia stereotipov [The Citizens of the Neighboring Countries and the Outsiders...The Dynamics of Stereotyping]. Druzhba narodov - Friendship of Peoples, 4, 166-186 [in Russian].

Dobaev, I.P., Serikov, A.V., \& Shevchenko, O.M. (2012). Agressivnost' kak faktor obostreniia molodezhnogo ekstremizma na luge Rossii [Aggressiveness as a Factor of Aggravation of the Youth Extremism in the South of Russia]. luzhno-rossiiskoe obozrenie - The Southern Russian Review, 71 [in Russian].

Erikson, E. (1968). Identity: Youth and Crisis (pp. 336). New York: W. W. Norton Company.

Gasanov, I.B. (1998). Natsional'nye stereotipy $i$ "obraz vraga». Psikhologiia natsional'noi neterpimosti [National Stereotypes and the "Enemy Image." The Psychology of National Intolerance] (pp. 560). Minsk: Harvest [in Russian].

Hagendorn, L. (1995). Etnicheskaia kategorizatsiia i diskriminatsiia: rol' kul'turnykh tsennostei $i$ obshchestvennykh stereotipov $v$ formirovanii etnicheskikh ierarkhii / Natsionalizm (Vzgliad iz-za rubezha) [The Ethnic Categorization and Discrimination: the Role of Cultural Values and Social Stereotypes in the Formation of Ethnic Hierarchies. The Nationalism (Views from Abroad)] (pp. 5378). Moscow, M.: The Russian Academy of Public Service under the President of the Russian Federation, the Information and Analytical Center, the Scientific and Information Department [in Russian].

Helbling, M. (2014). Opposing Muslims and the Muslim Headscarf in Western Europe. European Sociological Review, 30(2), 242-257. Iarskaia, V.N. (2012). My Tongue Is My Enemy: the Racist Discourse in the Russian Society. Sociological Studies, 6 [in Russian]. Kon, I.S. (1998). Psikhologiia predrassudka. O sotsial'no-psikhologicheskikh korniakh etnicheskikh predubezhdenii. Psikhologiia 
natsional'noi neterpimosti [The Psychology of Prejudice. On the Socio-Psychological Roots of Ethnic Prejudices. The Psychology of National Intolerance] (pp. 23, 33). Minsk: Harvest [in Russian].

Krech, R.S. (1962). Crutchfield and E.L. Ballachey. Individual in Society. New York.

Levin, M.I., Freer, M.L., \& Shilova, N.V. (2012). Ratsional'naia ksenofobiia: predskazuemye rezul'taty i neozhidannye posledstviia [The Rational Xenophobia: Predictable Results and Unexpected Consequences]. Finansy i biznes - The Finances and Business, Vol. 4, $35-47$ [in Russian].

Lubskii, A.V. (2012). Neoklassicheskaia model' sotsiologicheskogo issledovaniia [The Neoclassical Model of Sociological Research]. Sotsial'no-gumanitarnye znaniia - The Social-Humanitarian Knowledge, 7, 112-120 [in Russian].

Mukomel, V. (2014). Ksenofobiia i migrantofobiia v kontekste kul'tury doveriia [Xenophobia and Migrant-Phobia in the Context of the Culture of Trust]. Mir Rossii: Sotsiologiia, Etnologiia - The World of Russia: Sociology, Ethnology, 23(1), 137-166 [in Russian].

Popper, K. (1992). Otkrytoe obshchestvo i ego vragi [The Open Society and Its Enemies] (Vol.3, pp. 448). Moscow: Progress [in Russian].

Shevchenko, O.M. (2013). Sushchnost' i vidy ksenofobii: istoriia i sovremennost' [The Essence and Types of Xenophobia: History and Modernity] (pp. 203). Rostov on Don: Antei [in Russian].

Soldatova, G.U., \& Makarchuk, A.V. (2006). Mozhet li drugoi stat' drugom? Trening po profilaktike ksenofobii [Can an Outsider Become your Friend? Training on the Prevention of Xenophobia] (pp. 256). Moscow: Genezis [in Russian].

Sotsial'noe neravenstvo etnicheskikh grupp: predstavleniia i real'nost' [The Social Inequality of Ethnic Groups: Perceptions and Reality] (2002). Moscow: Academia [in Russian].

Sumner, W. (1959). Folkways. New York: Dover, Inc.

Tajel, H., \& Turner, J. (1979). An Integrative Theory of Social Conflict. In W. Austin and S. Worchel (Ed.), The Social Psychology of Integroup Relations (pp. 33-47). Monterey (Calif.): Brooks/Cole.

Tsygankov, A.P. (2013). The Russia-NATO Mistrust: Ethnophobia and the Double Expansion to Contain the "Russian Bear." Communist and Post-Communist Studies, 46(1), 179-188 [in Russian].

Van der Noll, J., \& Saroglou, V. (2015). Anti-Islam or Anti-Religion? Understanding Objection against Islamic Education. Journal of Ethnic and Migration Studies, 41(2), 219-238. 